\title{
LATERAL ENTRY PINNING AND CROSSED ENTRY PINNING IN PEDIATRIC SUPRACONDYLAR HUMERAL FRACTURES GARTLAND TYPE III
}

\author{
*Hesham Ahmed Fahmy, *Mostafa Mohamed Baraka, and \\ **Ahmed Ibrahim Ahmed Metwally
}

\begin{abstract}
*Department of Orthopaedic Surgery, Faculty of Medicine - Ain Shams University, Cairo, Egypt and

**Resident Orthopaedic Surgery at Berkat El Saba General Hospital

Corresponding author

Ahmed Ibrahim Ahmed Metwally

Mobile: (+2) 01093591223

E.mail:

ahmdeliwa6@gmail.com
\end{abstract}

Received: $13 / 5 / 2021$

Accepted: 2/6/2021

Online ISSN: 2735-3540

\begin{abstract}
:
Background: Supracondylar humeral fracture is a very common pediatric trauma disorder. It is very common between four and eleven years, more in boys than girls and left side affected more than right one. Major cases are extension type, which is sub classified according to Garteland classification by severity diagnosed radiologically through plain $x$-rays. Displaced fractures usually need fixation to avoid functional and cosmetic complications.
\end{abstract}

Aim of the Work: This systematic review of literature and metaanalysis is conducted to compare between two methods of closed pinning of Gartland's III supra-condylar humeral fractures comparing lateral entry wires and crossed wires according to ulnar nerve injury and postoperative clinical and radiological outcomes.

Patient and Method: Recent after 2000 clinical trials or cluster trials, prospective and retrospective comparative cohort studies. Search results will be uploaded to systematic review management software and manually screened for eligibility to be included. PRISMA (Preferred Reporting Items for Systematic Reviews and Meta-Analyses) flowchart will be introduced on the search results.

Data Sources: Medline databases (PubMed, Medscape, Science Direct. EMF-Portal) and all materials available in the Internet till 2020.

Results: Closed reduction and per-cutaneous pinning, of supracondylar humeral fractures in children by lateral only and crossed medial and lateral wires result in similar construct stability and functional outcome, and there was significant difference between the two managements as for the complications of ulnar nerve injury which is higher in crossed pinning.

Conclusion: Lateral pinning with proper technique for sake of safety and to minimize risk of ulnar nerve injury in addition to adequate stability if proper pin fixation principles are used.

Keywords: Supracondylar humeral fractures, closed reduction, crossed pinning

\section{INTRODUCTION:}

Supracondylar fracture of distal humerus (SCHF) is one of the common pediatric fractures that are encountered in orthopedics practice. Eighty-five percent of children are between 4-11 years of age. It accounts for around $3-7 \%$ of all pediatrics fractures. ${ }^{(1)}$

Untreated type III supracondylar fractures are the common cause for cubitus varus deformity ${ }^{(2)}$. The main aim of treatment in 
supracondylar fracture is to prevent such varus, and rotational deformity. There are various modalities of treatments that range from conservative to operative. Undisplaced fractures are treated conservatively. Gartland type III supracondylar fractures are very unstable fractures. They require proper reduction and stable fixation to prevent such deformity. ${ }^{(3)}$

The standard method of fixation of displaced fractures is closed reduction and per-cutaneous pinning. The aim of this study is to compare between lateral entry pinning and crossed pinning techniques according to safety and efficacy (functional and radiological). ${ }^{(4)}$

Crossed pinning provides increased biomechanical stability, but it carries the risk of iatrogenic ulnar nerve injury from the placement of the medial pin. On the other hand lateral pinning provides less biomechanical stability but less risk of ulnar nerve injury. ${ }^{(5)}$

Some authors believe that (two 'divergent' lateral pins or three lateral pins are equivalent in terms of rotational stability to crossed pins) and without having the risk of iatrogenic ulnar nerve injury. ${ }^{(6)}$

The literature is still lacking consensus about a certain number and configuration of pins. this study is conducted to compare between the crossed and lateral-only pins regarding the provided stability and the risk of ulnar nerve injury.

\section{AIM OF THE STUDY}

This systematic review of literature and meta-analysis is conducted to compare between two methods of closed pinning of Gartland's III supra-condylar humeral fractures comparing lateral entry wires and crossed wires according to ulnar nerve injury and post-operative clinical and radiological outcomes.

\section{METHODS:}

Types of studies: Recent after 2000 clinical trials or cluster trials, prospective and retrospective comparative cohort studies. Search results will be uploaded to systematic review management software and manually screened for eligibility to be included. PRISMA (Preferred Reporting Items for Systematic Reviews and Meta-Analyses) flowchart will be introduced on the search results.

Types of participants: Only human subjects aged (2-10 years old) with a recent fracture supracondylar humerus.

Types of interventions: Treatment by closed reduction and pinning either lateral pinning or crossed pinning by k-wires

Types of outcome measures: Neurologic (ulnar nerve injury) and vascular examination of the extremity. Flynn's criteria, ${ }^{(7)}$ which are based on the carrying angle and elbow motion, (table 5).

Table 1. Flynn crieteria ${ }^{(8)}$

\begin{tabular}{|l|c|c|c|}
\hline Results & Rating & $\begin{array}{c}\text { Cosmetic loss of } \\
\text { carrying angle } \\
\text { (deg.) }\end{array}$ & $\begin{array}{c}\text { Functional loss } \\
\text { of motion (deg.) }\end{array}$ \\
\hline Satisfactory & Excellent & $0-5$ & $0-5$ \\
& Good & $5-10$ & $5-10$ \\
& Fair & $10-15$ & $10-15$ \\
\hline Unsatisfactory & Poor & $>15$ & $>15$ \\
\hline
\end{tabular}




\section{Selection criteria for studies:}

Inclusion criteria: Prospective and retrospective comparative studies discussing the results of various techniques as surgical management of supracondylar humerus fracture in pediatric patients. Reporting functional outcomes following each technique. Studies conducted in English. Gartland type III supracondylar fracture. In period of 20002019. Human studies. Journal articles. Exclusion criteria. Studies conducted in other languages than English. Animal studies studies before 2000. Gartland type I and II supracondylar fractures

Search strategy for identification of study:

The search will be conducted by using the databases: Without restrictions on location or publication types: PubMed, EMBASE, the Cochrane Library, and the Google Scholar database. The Mesh terms and their combinations used in the search were as follows: "supracondylar humeral fractures" OR "SCHF" AND "closed reduction" AND "crossed pinning", "lateral pinning". The reference lists of related reviews and original articles were searched for any relevant studies.

\section{Methods of the review:}

Locating and selecting studies: Abstracts of articles identified using the search strategy above will be viewed, and articles that appear to fulfill the inclusion criteria will be retrieved in full. When there is doubt, a second reviewed will assess the article and consensus will be reached.

Data extraction: Data will be independently extracted by two reviewers and cross-checked.

\section{Statistical considerations:}

Outcomes from included trials will be combined using the systematic review manager software and manually screened for eligibility to be included. PRISMA flow-chart will be produced based on the search results and the inclusion/exclusion criteria to facilitate the assessment of possible risk of bias of each study, information will be collected using the (Cochrane collaboration tool for assessing the risk of bias). After pooling of the collected data from the desired search studies. The relative risk of each of the intended outcome measures of interest will be calculated.

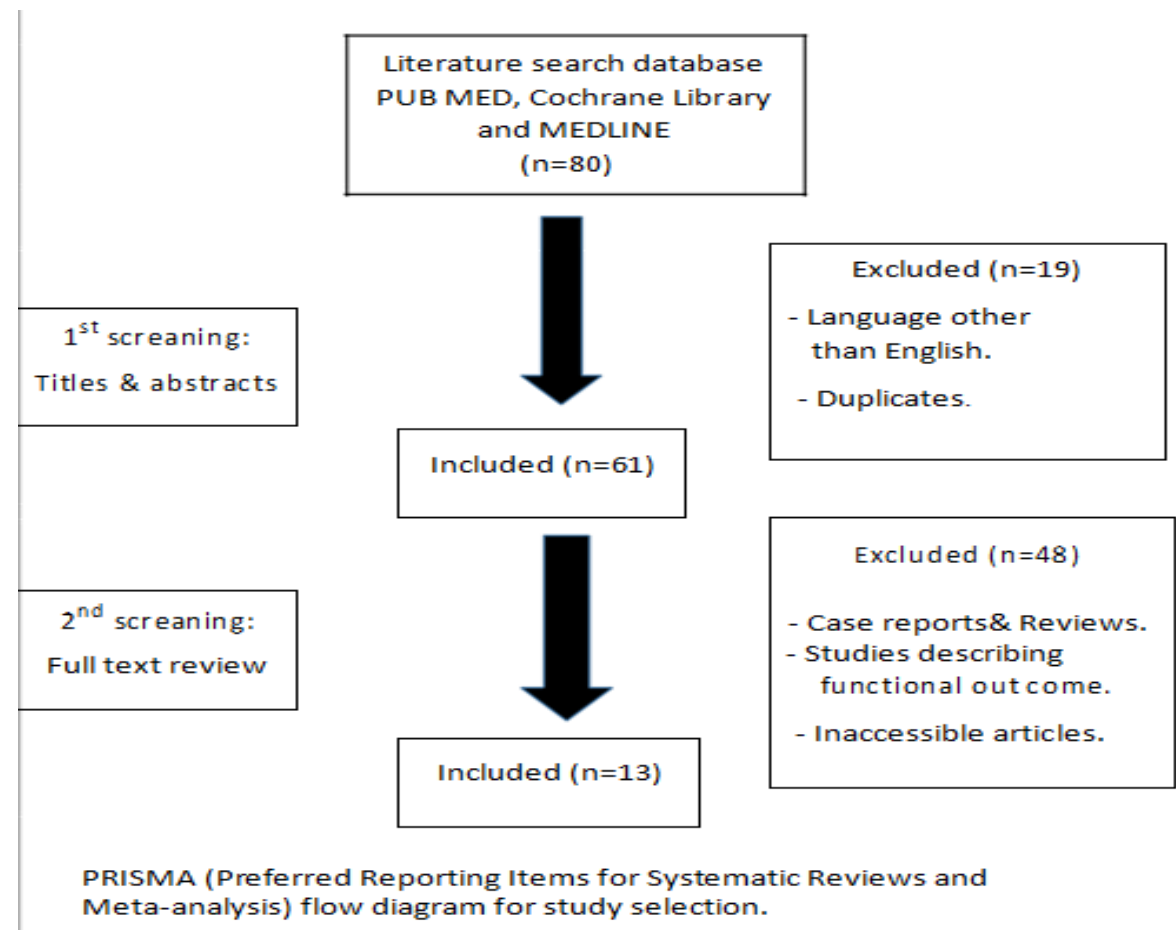

Diagram 1. PRISMA chart 


\section{Statistical methods}

Statistical analysis was done using the jamovi project (2019) [jamovi Version 1.0 Computer Software. [Retrieved from https://www.jamovi.org]

Assessment of heterogeneity: Studies included in meta-analysis were tested for heterogeneity of the estimates using the following tests: Cochran $\mathrm{Q}$ chi square test: A statistically significant test (P-value <0.1) denoted heterogeneity among the studies. Isquare $\left(\mathrm{I}^{2}\right)$ index which is interpreted as follows: $\mathrm{I}^{2}=0 \%$ to $40 \%$ : unimportant heterogeneity. $\mathrm{I}^{2}=30 \%$ to $60 \%$ : moderate heterogeneity. $\mathrm{I}^{2}=50 \%$ to $90 \%$ : substantial heterogeneity. $\mathrm{I}^{2}=75 \%$ to $100 \%$ : considerable heterogeneity.
Assessment of publication bias: Publication bias was assessed by: Examination of funnel plots of the estimated effect size on the horizontal axis versus a measure of study size (standard error for the effect size) on the vertical axis. In the presence of publication bias, the plots are asymmetrical. Begg and Mazumdar rank correlation analysis for asymmetry of funnel plot.Egger regression analysis for asymmetry of funnel plot.

Pooling of estimates: Binary outcomes are presented as log odds ratio with $95 \%$ confidence limits $(95 \% \mathrm{CI})$. Estimates from included studies were pooled using restricted maximum likelihood (REML) random-effects model. $\quad P$-value $<0.05$ is considered statistically significant.

\section{RESULTS:}

Table 2. Summary of included studies, comparing crossed versus lateral pinning.

\begin{tabular}{|l|l|l|l|}
\hline Authors & Year & Journal & Type \\
\hline Hossam et al. & 2019 & $\begin{array}{l}\text { The Egyptian Orthopaedic } \\
\text { Journal }\end{array}$ & Prospective randomized study \\
\hline Pavone et al. $^{(10)}$ & 2016 & J. Funct. Morphol. Kinesiol. & Retrospective study \\
\hline Pesenti et al. ${ }^{(1)}$ & 2017 & $\begin{array}{l}\text { Orthopedics\& traumatology } \\
\text { surgery\& research }\end{array}$ & Retrospective study \\
\hline Sapkota et al. ${ }^{(12)}$ & 2018 & $\begin{array}{l}\text { Asian Journal of Medical } \\
\text { Sciences }\end{array}$ & $\begin{array}{l}\text { Prospective non randomized } \\
\text { study }\end{array}$ \\
\hline Kocher et al. $^{(13)}$ & 2007 & $\begin{array}{l}\text { THE JOURNAL OF BONE } \\
\text { AND JOINT SURGERY }\end{array}$ & Prospective randomized study \\
\hline Prashant et al. ${ }^{(14)}$ & 2016 & J OrthopaedTraumatol & Prospective randomized study \\
\hline Palange et al. ${ }^{(15)}$ & 2019 & $\begin{array}{l}\text { International Journal of } \\
\text { Orthopaedics Sciences }\end{array}$ & Prospective randomized study \\
\hline Solak et al. ${ }^{(16)}$ & 2003 & $\begin{array}{l}\text { Journal of Pediatric Orthopaedics } \\
\text { B }\end{array}$ & Retrospective study \\
\hline Govindasamy et al. ${ }^{(17)}$ & 2016 & $\begin{array}{l}\text { International Journal of Research } \\
\text { in Orthopaedics }\end{array}$ & Retrospective study \\
\hline Naik et al. ${ }^{(18)}$ & 2017 & $\begin{array}{l}\text { Journal of Clinical and } \\
\text { Diagnostic Research. }\end{array}$ & $\begin{array}{l}\text { Prospective randomized study } \\
\text { Biomedical Research }\end{array}$ \\
\hline Baharti et al. ${ }^{(19)}$ & 2018 & $\begin{array}{l}\text { UNIVERSITY OF } \\
\text { SEYCHELLES American } \\
\text { Institute of medicine }\end{array}$ & $\begin{array}{l}\text { Pnternational Journal of } \\
\text { Orthopaedics Sciences }\end{array}$ \\
\hline Vaidya et al. ${ }^{(20)}$ & 2009 & Prospective randomized study \\
\hline
\end{tabular}


Lateral Entry Pinning And Crossed Entry Pinning In Pediatric Supracondylar Humeral Fractures..

Table 3. Number, sex ,side, age, follow up period of included studies.

\begin{tabular}{|c|c|c|c|c|c|c|c|c|c|}
\hline Study & $\begin{array}{c}\text { Number of } \\
\text { patients }\end{array}$ & Mean age & $\begin{array}{c}\text { Crossed } \\
\text { pins }\end{array}$ & $\begin{array}{c}\text { Lateral } \\
\text { only pins }\end{array}$ & $\begin{array}{c}\text { Mean } \\
\text { follow-up }\end{array}$ & Females & Males & $\begin{array}{c}\mathrm{Rt} \\
\text { side }\end{array}$ & $\begin{array}{l}\mathrm{Lt} \\
\text { side }\end{array}$ \\
\hline Hossam $^{(9)}$ & 67 & 5.4 vs 4.9 & 33 & 34 & 12 weeks & 22 & 45 & 15 & 42 \\
\hline Pavone ${ }^{(10)}$ & 35 & $\begin{array}{l}6.26 \text { vs } \\
5.69\end{array}$ & 22 & 13 & 12 months & 10 & 25 & 13 & 24 \\
\hline Pesenti $^{(11)}$ & 235 & 6.5 vs 6.3 & 177 & 58 & 4.7 months & 106 & 129 & & \\
\hline Sapkota ${ }^{(12)}$ & 34 & $\begin{array}{l}7.59 \text { vs } \\
7.53\end{array}$ & 17 & 17 & 6 months & 13 & 21 & & \\
\hline Kocher $^{(13)}$ & 52 & 5.7 vs 6.1 & 24 & 28 & 3 months & 29 & 23 & & \\
\hline Prashant ${ }^{(14)}$ & 62 & $\begin{array}{ll}8.55 & \text { vs } \\
8.25 & \\
\end{array}$ & 31 & 31 & 6 months & 17 & 45 & 14 & 48 \\
\hline Palange ${ }^{(15)}$ & 30 & $\begin{array}{l}6.52 \text { vs } \\
7.41\end{array}$ & 15 & 15 & 6 months & 19 & 11 & 12 & 18 \\
\hline Solak ${ }^{(16)}$ & 59 & 5 & 35 & 24 & 6 months & 43 & 16 & & \\
\hline Govindasamy $^{(17)}$ & 55 & 6.75 & 28 & 27 & 6 months & 22 & 33 & & \\
\hline Naik ${ }^{(18)}$ & 57 & $\begin{array}{l}6.28 \mathrm{vs} \\
7.25\end{array}$ & 29 & 28 & 12 months & 21 & 36 & 25 & 32 \\
\hline baharti ${ }^{(19)}$ & 45 & 6.7 & 28 & 17 & 12 month & 32 & 13 & 14 & 31 \\
\hline VAIDYA $^{(20)}$ & 60 & 5.8 vs 6.2 & 31 & 29 & 6 months & 22 & 38 & 26 & 34 \\
\hline Patil $^{(21)}$ & 30 & 8 & 15 & 15 & 6 months & 11 & 19 & 8 & 22 \\
\hline Total/mean & 821 & & 485 & 336 & & 367 & 454 & & \\
\hline
\end{tabular}

Table 4. Pooled outcome measures.

\begin{tabular}{|c|c|c|c|c|c|c|c|c|}
\hline \multirow[t]{2}{*}{ Study } & \multicolumn{2}{|c|}{$\begin{array}{l}\text { Ulnar } n \text {. injury } \\
\text { in crossed group }\end{array}$} & \multirow[t]{2}{*}{$\begin{array}{l}\text { Technique of medial } \\
\text { pin insertion }\end{array}$} & \multicolumn{4}{|c|}{ Flynn score } & \multirow[t]{2}{*}{$\begin{array}{c}\text { Other } \\
\text { complications }\end{array}$} \\
\hline & & $\begin{array}{c}\text { Study } \\
\text { participants }\end{array}$ & & Excellent & Good & fair & Poor & \\
\hline Hossam et al. ${ }^{(9)}$ & 0 & 33 & $\begin{array}{c}\text { Small incision } 1.5- \\
3.0 \mathrm{~cm}\end{array}$ & 27 & 4 & 1 & 1 & \\
\hline Pavone et al ${ }^{(10)}$ & 2 & 22 & $\begin{array}{l}\text { a landmark } \\
\text { on the medial } \\
\text { epicondyle }\end{array}$ & 21 & 1 & 0 & 0 & \\
\hline$\underset{(11)}{\text { Pesemti et al. }}$ & 7 & 177 & $\begin{array}{l}\text { A minimally } \\
\text { invasive } 2-\mathrm{cm} \\
\text { Approach }\end{array}$ & & & & 4 & \\
\hline Sapotka et al ${ }^{(12)}$ & 1 & 17 & Not mentioned & 11 & 5 & 1 & 0 & $\begin{array}{l}2 \text { radial palsy } \\
5 \text { pin tract } \\
\text { infection }\end{array}$ \\
\hline Kocher et al. ${ }^{(13)}$ & 0 & 24 & $\begin{array}{c}\text { A small medial } \\
\text { incision of } 1.5 \text { to } 3.0 \\
\mathrm{~cm} \text { over the medial } \\
\text { epicondyle. }\end{array}$ & 19 & 4 & 1 & 0 & \\
\hline$\underset{(14)}{\operatorname{Prashant}}$ et al. & 2 & 31 & $\begin{array}{c}\text { extended elbow and } \\
\text { the ulnar nerve } \\
\text { rolled } \\
\text { back with the } \\
\text { opposite thumb }\end{array}$ & 26 & 5 & 0 & 0 & $\begin{array}{l}4 \text { pin tract } \\
\text { infection }\end{array}$ \\
\hline Palange et al. ${ }^{(15)}$ & 3 & 15 & $\begin{array}{l}\text { small incision was } \\
\text { taken }\end{array}$ & 10 & 4 & 1 & 0 & \\
\hline Solak et al. ${ }^{(16)}$ & 2 & 35 & Not mentioned & 21 & 8 & 6 & 0 & $\begin{array}{c}1 \text { median nerve } 4 \\
\text { anterior inter } \\
\text { osseus } n \text { inj }\end{array}$ \\
\hline $\begin{array}{l}\text { Govindasamy et } \\
\text { al. }{ }^{(17)}\end{array}$ & 3 & 28 & Elbow extension & 22 & 6 & 0 & 0 & \\
\hline Naik et al. ${ }^{(18)}$ & 2 & 29 & small incision was & 23 & 0 & 6 & 0 & \\
\hline
\end{tabular}


Hesham Ahmed Fahmy, et al.,

\begin{tabular}{|c|c|c|c|c|c|c|c|c|}
\hline & & & taken & & & & & 0 \\
\hline Baharti et al. $^{(19)}$ & 2 & 28 & Elbow extension & 23 & 5 & 0 & $\begin{array}{c}3 \text { pin tract } \\
\text { infection }\end{array}$ \\
\hline $\begin{array}{c}\text { VAIDYA et al. } \\
\text { (20) }\end{array}$ & 3 & 31 & $\begin{array}{c}2-3 \text { cm medial } \\
\text { incisioin }\end{array}$ & 24 & 5 & 2 & 0 & $\begin{array}{c}3 \text { pin tract } \\
\text { infection }\end{array}$ \\
\hline Patil et al. $^{(21)}$ & 1 & 15 & $\begin{array}{c}\text { Rolling, elbow } \\
\text { extension }\end{array}$ & 10 & 5 & 0 & 0 & \\
\hline
\end{tabular}

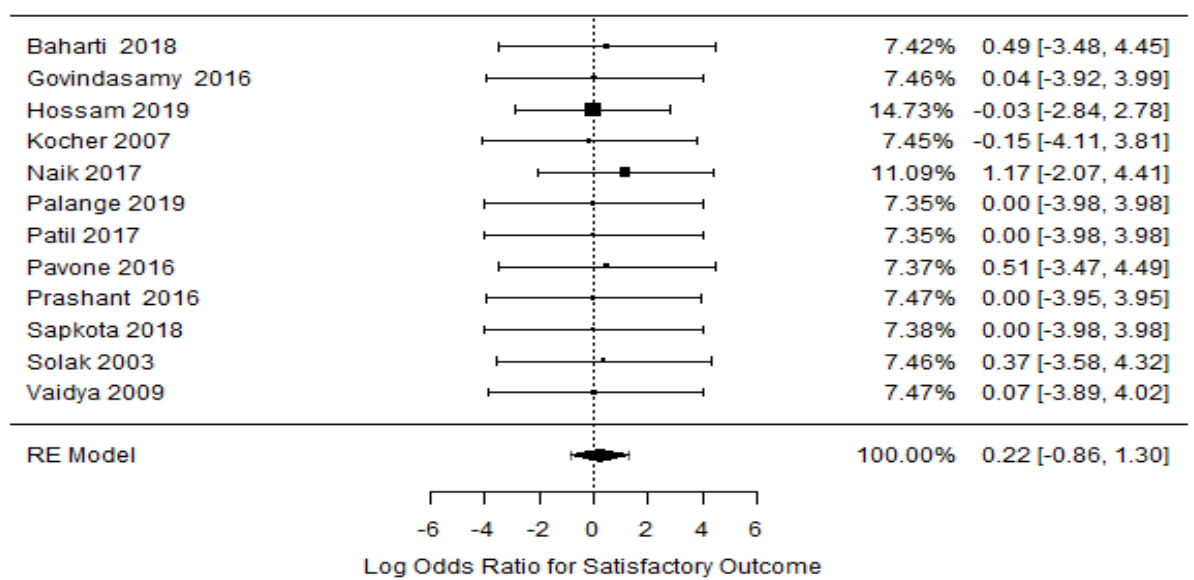

Diagram 2. Forest plot for achievement of satisfactory (fair to excellent) outcome as per Flynn's criteria

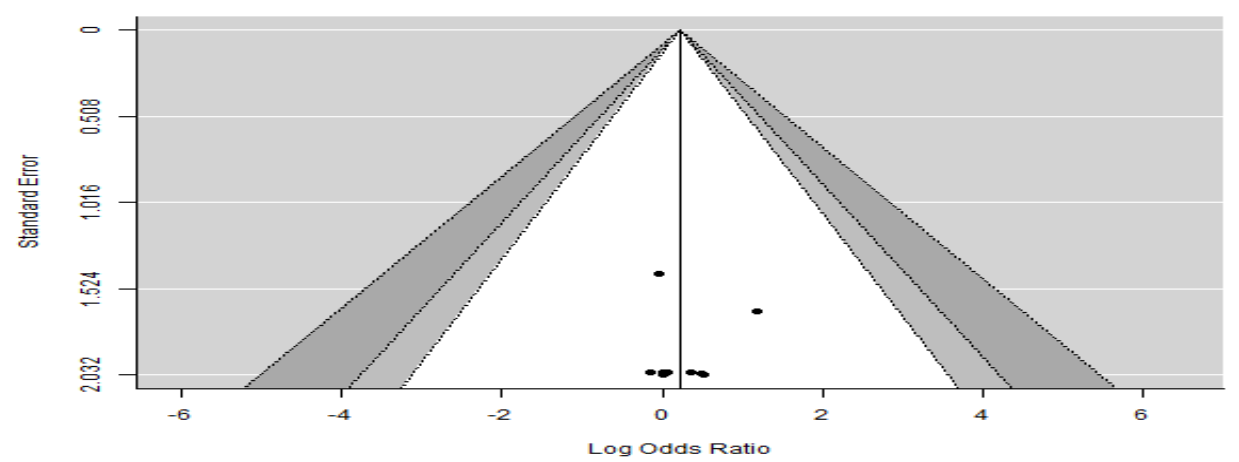

Diagram 3. Funnel plot for achievement of satisfactory (fair to excellent) outcome as per Flynn's criteria. 
Lateral Entry Pinning And Crossed Entry Pinning In Pediatric Supracondylar Humeral Fractures..

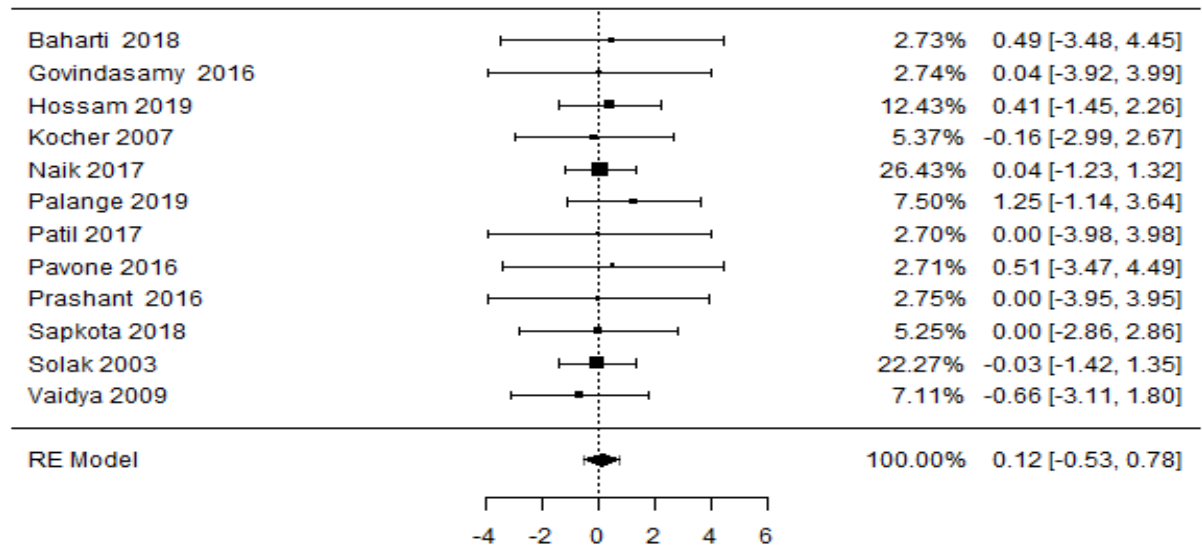

Log Odds Ratio for Excellent/Good Outcome

Diagram 4. Forest plot for achievement of excellent/good outcome as per Flynn's criteria

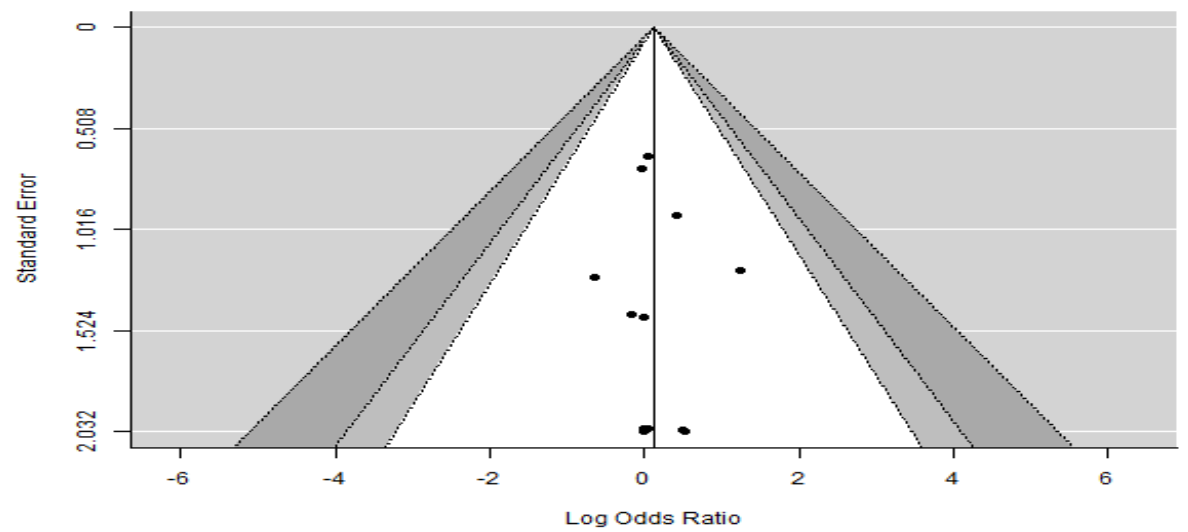

Diagram 5. Funnel plot for achievement of excellent/good outcome as per Flynn's criteria

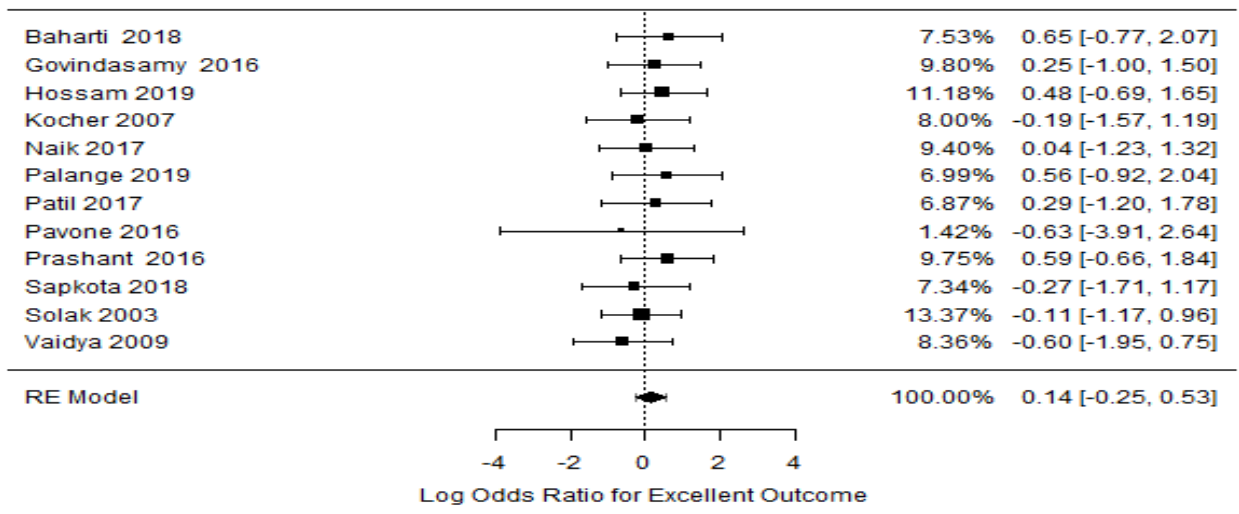

Diagram 6. Forest plot for achievement of excellent outcome as per Flynn's criteria 


\section{Hesham Ahmed Fahmy, et al.,}

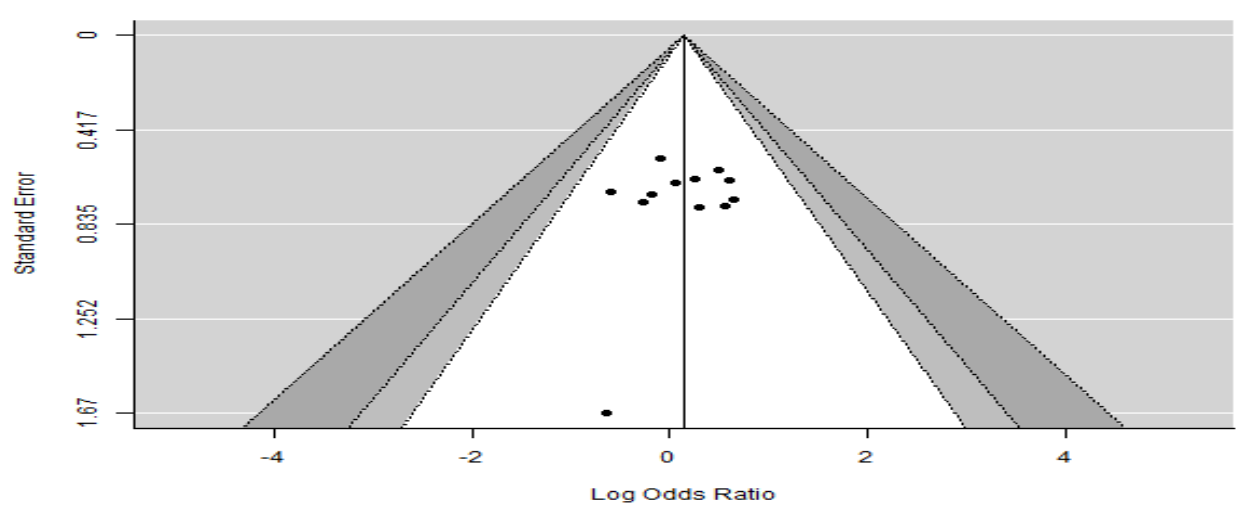

Diagram 7 Funnel plot for achievement of excellent outcome as per Flynn's criteria

Table 5. Incidence of iatrogenic ulnar nerve injury

\begin{tabular}{|c|c|c|c|}
\hline Technique & Ulnar nerve injury & Total & Incidence \\
\hline Crossed pining & 28 & 485 & $5.7 \%$ \\
\hline
\end{tabular}

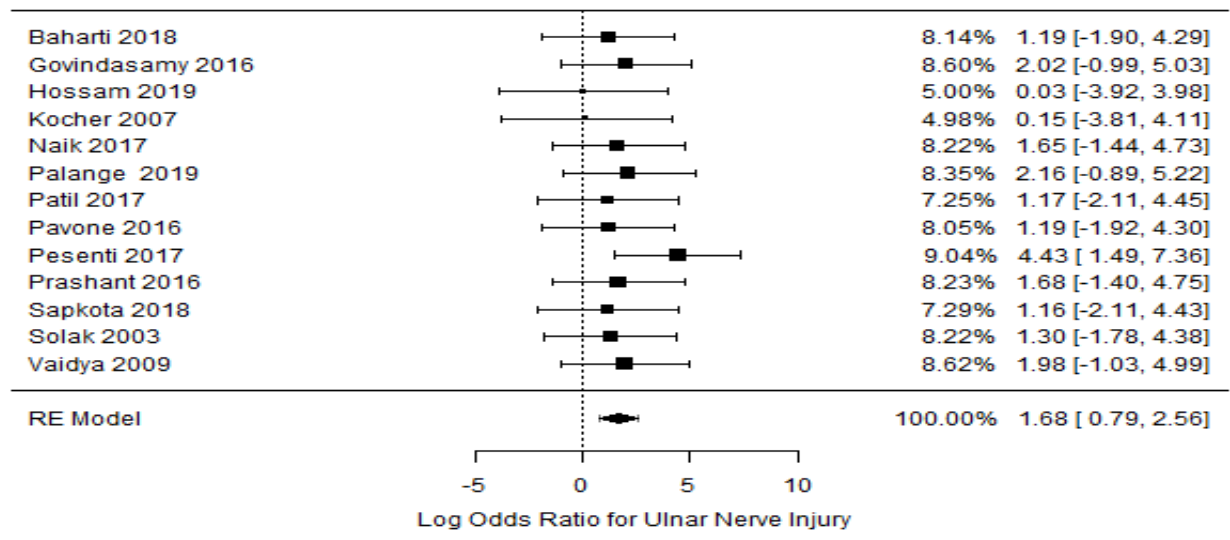

Diagram 8 Forest plot for risk of ulnar nerve injury. Crossed-entry pinning is associated with higher risk for ulnar nerve injury which is statistically significant ( $\log$ odds ratio $=1.68,95 \% \mathrm{CI}=0.79$ to 2.56 ). There is unimportant heterogeneity across studies (I-squared $=0 \%$, Cochran $\mathrm{Q}$ test P-value $=0.950$ ). 


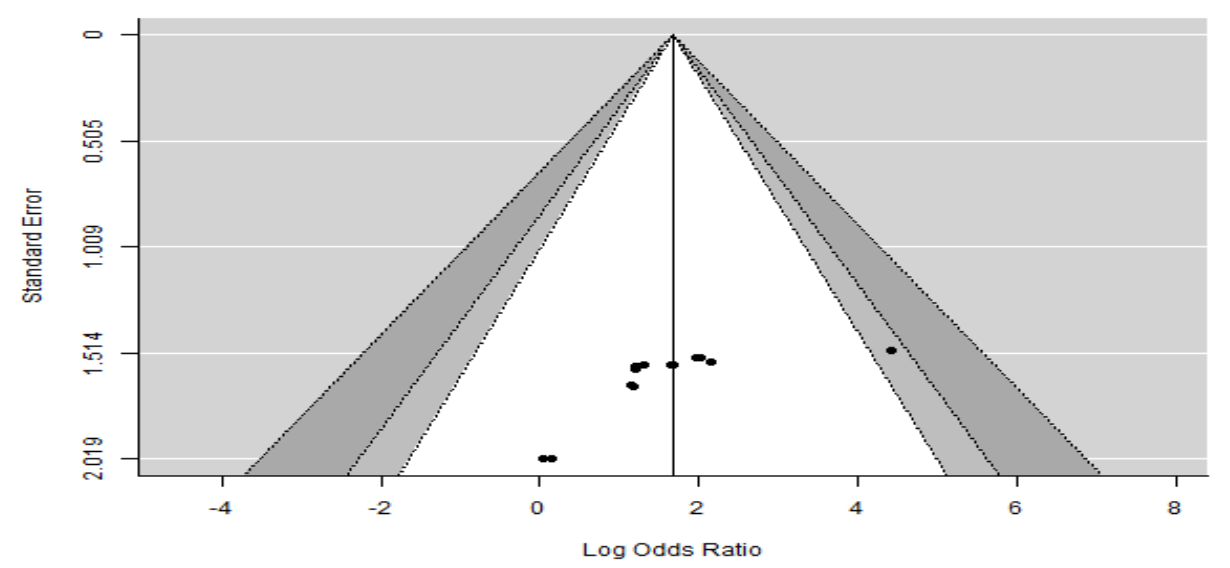

Diagram 9 Funnel plot for risk of ulnar nerve injury

Table 6. A summary of the results of similar meta-analysis.

\begin{tabular}{|c|c|c|c|c|}
\hline Authors & Date & $\begin{array}{c}\text { No of studies } \\
\text { included }\end{array}$ & Stability & $\begin{array}{l}\text { Iatrogenic ulnar } \\
\text { nerve injury }\end{array}$ \\
\hline O L Carrazone $^{(22)}$ & 2020 & 12 ( 930 patient) & Crossed pinning more stable & higher risk in Crossed \\
\hline $\mathrm{Y} \mathrm{Na}^{(23)}$ & 2018 & 24 (2222 patient $)$ & Crossed pinning more stable & higher risk in Crossed \\
\hline A E Dekker ${ }^{(24)}$ & 2016 & 13 (1158 patient) & No difference & higher risk in Crossed \\
\hline P Woratanart ${ }^{(25)}$ & 2012 & 18 (1615 patient) & No difference & higher risk in Crossed \\
\hline T Yousri ${ }^{(26)}$ & 2012 & 2 & No difference & higher risk in Crossed \\
\hline C A Brauer ${ }^{(27)}$ & 2007 & 35(2054 patient) & Crossed pinning more stable & higher risk in Crossed \\
\hline
\end{tabular}

\section{DISCUSSION:}

The ideal treatment for displaced supracondylar humeral fractures, according to many authors, is closed reduction and percutaneous pinning. A debate between the two fixation techniques by K-wires; lateral pins only and crossed (lateral and medial) pins still exists with ne consensus considering biomechanical stability and the risk of iatrogenic nerve injury. Although iatrogenic ulnar nerve injuries usually resolve, several permanent iatrogenic ulnar nerve injuries have been described. ${ }^{(28)}$

In the current study, we found that closed reduction and percutaneous pinning utilizing both techniques has comparable clinical outcomes according to the Flynn's criteria, with a significantly higher risk of iatrogenic ulnar nerve injury in the crossed group.
The selection of the appropriate surgical technique is important for the maintenance of reduction and to avoid iatrogenic ulnar nerve injury. The positioning of the fracture within acceptable radiographic parameters and the stabilization and proper positioning of the wires are crucial points for good outcomes. ${ }^{(29)}$

Crossed pinning was considered more biomechanically stable compared to lateral only pins as reported by Zionts et $\mathrm{al}^{(30)}$, while other authors as Skaggs et al. ${ }^{(31)}$ believed that no stability difference when considering technical points like maximizing separation of the pins at the fracture site, engaging the medial and lateral columns proximal to the fracture, engaging sufficient bone in both the proximal segment and the distal fragment and pin diameter and torsional stability intra operative advised by Bloom et al. ${ }^{(32)}$ with addition of third lateral pin if not stable after two give same stability as medial pin without risk of ulnar nerve injury. Arino et al. (33) recommended the use of two lateral pins to 
avoid injury to the ulnar nerve, and two recent meta-analyses ${ }^{(34,35)}$ support this recommendation.

The reviewed articles have concluded that medial-entry pinning, may have a higher risk of ulnar nerve injury with no significant difference regarding stability and postoperative outcomes according to Flynn criteria.

Other systematic reviews were conducted comparing both techniques of fixation have reported similar results. ${ }^{(24)(25)(26)}$ However, Carrazone et al. ${ }^{(22)}$,Y Na et al. ${ }^{(23)}$ and Brauer et al. ${ }^{(27)}$ reported that crossed pinning as more stable with less post-operative displacement, but with a higher risk of ulnar nerve injury compared to lateral group.

There are a number of limitations in the current study, some inherent to all systematic reviews, and some particular to our review.

First, the studies included in our analysis did not describe the same in technique of medial pin insertion. A small incision or palpation of nerve with elbow extension are believed to be a big concern on iatrogenic ulnar nerve injury, as risk of injury could be minimized up to $0 \%$ when minimal incision as done by kocher et al. ${ }^{(13)}$ and Hossam et al. ${ }^{(9)}$. But reported cases of ulnar nerve injury are still in range for previous reports and did not have major effect on iatrogenic nerve injury.

A second limitation is including lower number of studies with Gartland III fractures only despite there are many studies on displaced SCHF Gartland type II and III.

Another limitation is that some studies conducted lateral pins either by two or three $\mathrm{K}$-wires which may account for difference in torsional stability as highlighted by Gordon et al. ${ }^{(36)}$ however this did not affect instability compared to other studies using $3 \mathrm{k}$-wires only. Despite these concerns, the results presented in this review are the most up to date and can be useful in the clinical appraisal of supracondylar humeral fractures.
With regard to general recommendations for clinical practice, the closed reduction and percutaneous fixation of displaced SCFH has satisfactory results, regardless of the technique employed. This review suggests that the lateral wire technique should be used whenever possible, due to the increased risk of neurological lesions with crossed wire fixation. However, for unstable fractures, such as type III with medial comminution, for which a medial wire is found to be necessary, we suggest the use of the crossed wire technique, with special care taken to prevent injury to the ulnar nerve. The use of a minimedial incision to identify the ideal entry point for the wire in the epicondyle is recommended.

Lastly we recommend larger prospective randomized controlled studies to be done including a larger number of patients done comparing lateral three pins with medial and lateral pins. With comparison of results including iatrogenic injury of all nerves including radial and median nerves which are at risk during reduction and fixation in both techniques. Revise sentence

\section{Conclusion:}

Closed reduction and per-cutaneous pinning, of supracondylar humeral fractures in children by lateral only and crossed medial and lateral wires result in similar construct stability and functional outcome. And there was significant difference between the two managements as for the complications of ulnar nerve injury which is higher in crossed pinning, so we recommend lateral pinning with proper technique for sake of safety and to minimize risk of ulnar nerve injury in addition to adequate stability if proper pin fixation principles are used.

\section{REFERENCES:}

1. Temple A, Bache CE, Gibbons PJ. Fractures of the elbow: supracondylar fractures. Trauma 2006; 8:123-130. 
2. Chen RS, Liu CB, Lin XS, Feng XM, Zhu JM, Ye FQ. Supracondyla Extension fracture of the humerus in children. J Bone Joint Surg 2001; 83B:883-887.

3. Tolo VT, Skaggs DL, eds. Master Techniques in Orthopaedic Surgery: Pediatric Orthopaedics. Philadelphia: Lippincott, 2007: $1-15$.

4. Maity A, Saha D, Roy DS. A prospective randomised, controlled clinical trial comparing medial and lateral-entry pinning with lateral entry pinning for percutaneous fixation of displaced extension type supracondylar fractures of the humerus in children. J Orthop Surg Res 2012; 7:1-8.

5. Beaty JH, Kasser JR. Rockwood and Wilkins' fractures in children. Vol. 3. 5th ed. Philadelphia, Pennsylvania: Lippincott Willams \& Wikins; 2001. 576-624

6. Brauer CA, Lee BM, Bae DS, Waters PM, Kocher MS. A systematic review of medial and lateral entry pinning versus lateral entry pinning for supracondylar fractures of the humerus. J Pediatr Orthop 2007; 27: 181-186.

7. Omid R, Choi PD, Skaggs DL. Supracondylar humeral fractures in children. J Bone Joint Surg Am. 2008 May;90(5):1121-32.

8. Flynn JM, Sarwark JF, Waters PM, Bae DS, Lemke LP. The operative management of pediatric fractures of the upper extremity. $\mathbf{J}$ Bone Joint Surg Am 2002; 84:2078-2089.

9. Abubeih HM, El-Adly W, El-Gaafary K, Bakr $\mathrm{H}$. Percutaneous cross-pinning versus two lateral entry pinning in Gartland type III pediatric supracondylar humerus fractures. Egypt Orthop J 2019;54:52-61

10. Pavone, V.; Riccioli, M.; Testa, G.; Lucenti, L.; De Cristo, C.; Condorelli, G.; Avondo, S.; Sessa, G. Surgical Treatment of Displaced Supracondylar Pediatric Humerus Fractures: Comparison of Two Pinning Techniques. $J$. Funct. Morphol. Kinesiol. 2016, 1, 39-47.

11. Pesenti S, Ecalle A, Gaubert L, Peltier E, Choufani E, Viehweger E, Jouve JL, Launay F. Operative management of supracondylar humeral fractures in children: Comparison of five fixation methods. Orthop Traumatol Surg Res. 2017 Sep;103(5):771-775.
12. Sapkota, Krishna \& Wahegaonkar, Krishna \& Ranjeet, Niraj \& Thapa, Pabin \& Thapa, Upendra \& Onta, Pratyenta. (2019). Comparison of cross pinning versus lateral three pins in type three supracondylar fracture of distal humerus in children.. Asian Journal of Medical Sciences. $10 . \quad 58-61$. 10.3126/ajms.v10i2.22034.

13. Kocher MS, Kasser JR, Waters PM, Bae D, Snyder BD, Hresko MT, et al. Lateral entry compared with medial and lateral entry pin fixation for completely displaced supracondylar humeral fractures in children. A randomized clinical trial. J Bone Joint Surg Am 2007; 89:706-712.

14. Prashant K, Lakhotia D, Bhattacharyya TD, Mahanta AK, Ravoof A. A comparative study of two percutaneous pinning techniques (lateral vs medial-lateral) for Gartland type III pediatric supracondylar fracture of the humerus. $J$ Orthop Traumatol. 2016;17(3):223-229.

15. Nikhil D Palange, Dr. Prasannakumar GS, Dr. Akash Mane, Dr. Eknath Pawar. A comparison between percutaneous cross $\mathrm{k}$ wire and lateral $\mathrm{k}$ wires fixation in management of Type III Gartland paediatric supracondylar fractures. Int J Orthop Sci 2019;5(2):119-122.

16. Solak $S$ and Aydn E. Comparison of two percutaneous pinning methods for the treatment of the pediatric type III supracondylar humerus fractures. Journal of Pediatric Orthopaedics B 2003; 12(5):346-349.

17. Govindasamy, Rajesh \& Gnanasundaram, Ramkumar \& Kasirajan, Saravanan \& Thonikadavath, Fawas \& Tiwari, Rajeev. (2016). Cross pinning versus lateral pinning in type III supracondylar fracture: a retrospective analysis:. International Journal of Research in Orthopaedics. 4510.IntJResOrthop20162619.

18. Naik LG, Sharma GM, Badgire KS, Qureshi F, Waghchoure C, Jain V. Cross Pinning Versus Lateral Pinning in the Management of Type III Supracondylar Humerus Fractures in Children. J Clin Diagn Res. 2017;11(8):RC01$\mathrm{RC} 03$. 


\section{Hesham Ahmed Fahmy, et al.,}

19. Sanjay R. Bharti Ashish K Magdum.A Comparative Study of Crossed Pinning Versus Lateral Pinning by Percutaneous K-wire in Paediatric Supracondylar Fractures of Humerus/ International Journal of Biomedical Research 2018; 09(09): 325-329.

20. Vaidya SM. Percutaneous fixation of displaced supracondylar fracture in children comparing lateral with medial and lateral pin. A thesis submitted to university of Seychelles American institute of medicine. 2009. Available at: http://www.mch-

orth.com/pdf/Thesis\%20by\%20Dr.Sudeep\%20 Vaidya.pdf. Accessed 17 Apr 2013.

21. Patil S, Gaonkar N, Pandey P, Shubham K, Shah R, Garud A et al. A comparative study of two percutaneous pinning techniques (Cross K wire vs Lateral $\mathrm{K}$ wire) for Gartland type III pediatric supracondylar fracture of the humerus. International Journal of Orthopaedics Sciences. 2017; 3(4):665-668.

22. Oreste Lemos Carrazzone, Nacime Salomão Barbachan Mansur, Fábio Teruo Matsunaga, Marcelo Hide Matsumoto, Flavio Faloppa, João Carlos Belloti, Marcel Jun Sugawara Tamaoki . Crossed versus lateral K-wire fixation of supracondylar fractures of the humerus in children: a meta-analysis of randomized controlled trials, Journal of Shoulder and Elbow Surgery. 2021: 30(2):439448.

23. Na Y, Bai R, Zhao Z, et al. Comparison of lateral entry with crossed entry pinning for pediatric supracondylar humeral fractures: a meta-analysis. J Orthop Surg Res. 2018;13(1):68.

24. Dekker AE, Krijnen P, Schipper IB. Results of crossed versus lateral entry K-wire fixation of displaced pediatric supracondylar humeral fractures: A systematic review and metaanalysis. Injury. 2016 Nov;47(11):2391-2398.

25. Woratanarat $\mathrm{P}$, Angsanuntsukh C, Rattanasiri S, Attia J, Woratanarat T, Thakkinstian A. Meta-analysis of pinning in supracondylar fracture of the humerus in children. J Orthop Trauma. 2012 Jan;26(1):48-53.
26. Yousri T, Tarassoli P, Whitehouse M, Monsell F, Khan WS. Systematic review of randomized controlled trials comparing efficacy of crossed versus lateral K-wire fixation in extension type Gartland type III supracondylar fractures of the humerus in children. Ortop Traumatol Rehabil. 2012 Sep-Oct;14(5):397-405.

27. Brauer CA, Lee BM, Bae DS, Waters PM, Kocher MS. A systematic review of medial and lateral entry pinning versus lateral entry pinning for supracondylar fractures of the humerus. J Pediatr Orthop. 2007;27:181-6.

28. Ramachandran M, Birch R, Eastwood DM. Clinical outcome of nerve injuries associated with supracondylar fractures of the humerus in children. The experience of a specialist referral centre. J Bone Joint Surg Br 2006;88(1):90-94.

29. Abzug JM, Herman MJ. Management of supracondylar humerus fractures in children: current concepts. J Am Acad Orthop Surg 2012;20(2):69-77.

30. Zionts LE, McKellop HA, Hathaway R. Torsional strength of pin configurations used to fix supracondylar fractures of the humerus in children. J Bone Joint Surg Am 1994; 76(2):253-256.

31. Skaggs DL, Cluck MW, Mostofi A, et al. Lateral-entry pin fixation in the management of supracondylar fractures in children. $\mathrm{J}$ Bone Joint Surg Am 2004;86A(4):702-707.

32. Bloom $\mathrm{T}$, Mahar A, Pring $\mathrm{M}$, et al. Comparison of supracondylar humerus fracture pinning when the fracture is not anatomically reduced. Presented at the 34th Annual David H. Sutherland Pediatric Orthopedic Visiting Professorship; May 17-18, 2007.

33. Ariño VL, Lluch EE, Ramirez AM, et al. Percutaneous fixation of supracondylar fractures of the humerus in children. J Bone Joint Surg Am 1977;59(7):914-916.

34. Ramachandran M, Birch R, Eastwood DM. Clinical outcome of nerve injuries associated with supracondylar fractures of the humerus in children. The experience of a specialist referral centre. J Bone Joint Surg Br 2006;88(1):90-94.

35. Rasool MN. Ulnar nerve injury after K-wire fixation of supracondylar humerus fractures in children. J Pediatr Orthop 1998;18(5):686-690. 
36. Gordon JE, Patton CM, Luhmann SJ, et al. Fracture stability after pinning of displaced supracondylar distal humerus fractures in children. J Pediatr Orthop 2001;21(3): 313318.

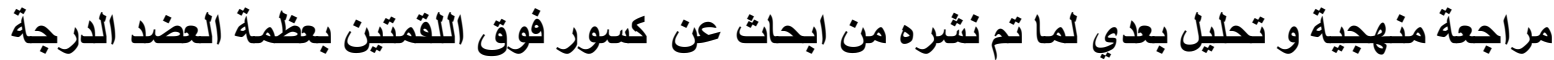 الثالثة عند الاطفال مقارنة التثبيت باسلاك متقاطعة التثبيت مع التثبيت باسلاك من من الناحية الوحثية فقط}

$$
\begin{aligned}
& \text { * هشام أحمد فهمي، *مصطقي تحما بركة، **أحمد إبراهيم أحمد متولي } \\
& \text { *قسم جر احة العظام، كلية الطب - جامعة عين شمس } \\
& \text { ***بيب ميقم ، مستشفي بركة السبع العام }
\end{aligned}
$$

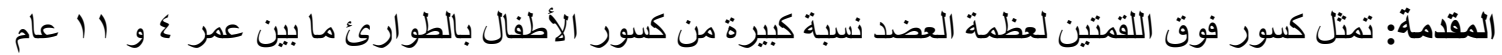

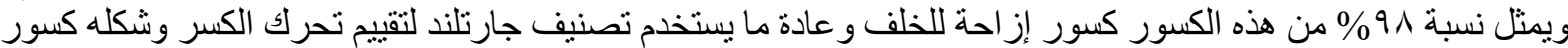
الدرجة الثالثة جار تلند عادة ما تحتاج إلى التثبيت بو اسطة أسلاك معدنية.

الهلف من البحث: مراجعة منهجية وتحليل بعدي لما تم نشره من أبحاث عن كسور فوق اللقمتين بعظمة العضد

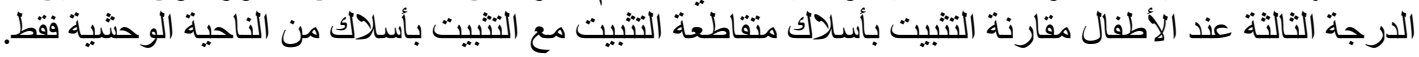

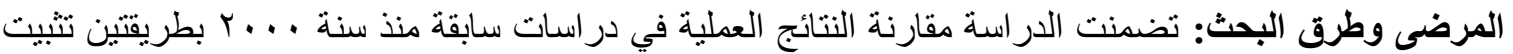

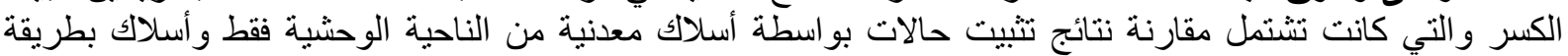
متقاطعة

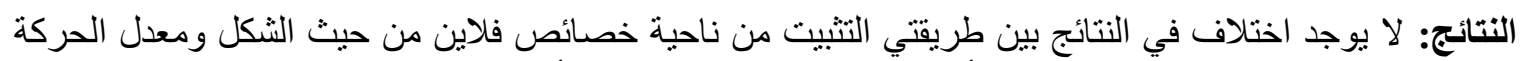
في حين احتمالية حدوث إصابة العصب الزندي أكثر في طريقة التثبيث بو اسطة أسلاك منقاطعة. الاستنتاج: يوصى بتثبيت من الناحية الوحشية فقط مع مر اعاة الإجراءات الصحيحة لتناكيد ثبات الكسر وتفادي

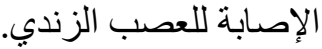

